MaPan : Jurnal Matematika dan Pembelajaran

p-ISSN: 2354-6883 ; e-ISSN: 2581-172X

Volume 6, No 1, June 2018 (94-103)

DOI: https://doi.org/10.24252/mapan.2018v6n1a9

\title{
IMPLEMENTASI MODEL OSBORN DENGAN TEKNIK MNEMONIC MELALUI TEORI KONSTRUKTIVISME TERHADAP KEMAMPUAN PEMECAHAN MASALAH MATEMATIS
}

\author{
Sinta Oktavianti1), Farida'), Fredi Ganda Putra ${ }^{3)}$ \\ 1,2,3 UIN Raden Intan Lampung \\ 1,2,3 Jl. Letnan Kolonel H. Endro Suratmin, Sukarame, Kota Bandar Lampung, \\ Lampung \\ E-mail: $\underline{\text { sintaokta76@gmail.com }}{ }^{1)}, \underline{\text { farida@gmail.com }}^{2}$, $\underline{\text { fredigpsw@gmail.com }}^{3}$
}

Submitted: 17-02-2018, Revised: 23-05-2018, Accepted: 01-06-2018

\begin{abstract}
Abstrak:
Penerapan model osborn dengan teknik mnemonic diharapkan bisa memperbaiki rendahnya kemampuan pemecahan masalah matematis. Tujuan penelitian ini adalah untuk mengetahui adanya pengaruh model pembelajaran osborn dengan teknik mnemonic melalui teori konstruktivisme terhadap kemampuan pemecahan masalah matematis peserta didik. Penelitian ini merupakan penelitian kuantitatif jenis quasi eksperimental design. Sampel penelitian terdiri dari tiga kelompok yang akan diberikan perlakuan yang berbeda yaitu: kelompok sampel pertama akan diterapkan model pembelajaran osborn dengan teknik mnemonic melalui teori konstruktivisme, kelompok sampel yang kedua diterapkan model pembelajaran osborn, dan kelompok sampel yang ketiga diberikan model pembelajaran konvensional. Uji hipotesis dalam penelitian ini menggunakan uji ANAVA satu jalur dengan sel tak sama. Hasil peneilitian ini adalah terdapat pengaruh model pembelajaran osborn dengan teknik mnemonic melalui teori konstruktivisme terhadap kemampuan pemecahan masalah matematis peserta didik.
\end{abstract}

Kata Kunci: Model Osborn, Mnemonic, Konstruktivisme, Pemecahan Masalah Matematis

\section{IMPLEMENTATION OF OSBORN MODELS WITH MNEMONIC TECHNIQUE THROUGH THE CONSTRUCTIVITY THEORY OF ABOUT THE ABILITY OF MATHEMATIC PROBLEM}

\begin{abstract}
:
Problem-solving skills are important. However, some existing studies suggest that students' mathematical problem solving skills are still low. The low ability of problem solving of mathematical learners is caused because students are still difficulty in solving math problems and less active in learning process in class. Application of osborn model with mnemonic technique is expected to fix the problem. The purpose of this study is to determine the influence of osborn learning model with mnemonic technique through constructivism theory to the problem solving ability of mathematical learners. This research is quantitative research quasy experimental design type. Hypothesis test in this research use ANAVA test one way with different cell. The result of this research is that there is influence of osborn learning model with
\end{abstract}


mnemonic technique through constructivism theory to students' mathematical problem solving ability.

Keywords: Osborn Model, Mnemonic, Constructivism Theory, Mathematical Problem Solving

How to Cite: Oktavianti, S., Farida, \& Putra, F. G. (2018). Implementasi Model Osborn dengan Teknik Mnemonic melalui Teori Konstruktivisme terhadap Kemampuan Pemecahan Masalah Matematis. MaPan : Jurnal Matematika dan Pembelajaran, 6 (1), 94-103.

$\mathrm{P}$ endidikan pada dasarnya adalah kebutuhan manusia guna menghadapi kemajuan tehnologi dan ilmu pengetahuan. Pendidikan merupakan usaha sadar dan terencana untuk mewujudkan suasana belajar dan proses pembelajaran agar peserta didik secara aktif mengembangkan potensi dirinya untuk memiliki kekuatan spiritual keagamaan, kepribadian, kecerdasan, serta keterampilan yang diperlukan dirinya dan masyarakat (Yusnita, Masykur, \& Suherman., 2016). Pendidikan menjadi satu-satunya jalan agar manusia menjadi lebih baik lagi. Bukunola dalam Widyawati menyatakan bahwa pendidikan merupakan salah satu cara dalam mengenalkan pada manusia untuk memiliki pengetahuan dan sikap yang lebih baik (Widyawati, 2017). Karena pendidikan itu kegiatan yang kompleks, dimensinya luas, dan dipengaruhi oleh banyak variabel (Masykur, Nofrizal, \& Syazali, 2017). Salah satu faktor yang mempengaruhi berhasil atau tidaknya suatu proses pendidikan adalah proses pembelajaran yang berlangsung di kelas khususnya mata pelajaran matematika.

Mata pelajaran Matematika sebagai salah satu ilmu yang tidak kalah pentingnya dalam upaya meningkatkan mutu pendidikan dan kehidupan bangsa. Matematika merupakan mata pelajaran yang penting. Paradigma dalam pembelajaran matematika membawa dampak pada penekanan pada perubahan siswa dalam proses pembelajaran. Perubahan tersebut mengubah fokus seluruh paradigma dalam suatu pendidikan matematika di seluruh dunia. (Kilpatrick, Swafford, \& \& Findell, 2001; Greer, Verschaffel, \& Mukhopadhyay, 2007). Melalui pelajaran matematika siswa akan mampu belajar untuk memperoleh pengetahuan secara sistematis ataupun cara memecahkan suatu masalah matematis (Aida \& Widjajanti, 2014; Wulandari, Mujib, \& Putra, 2016).

Menurut (Ormrod, 2008), pemecahan masalah adalah menggunakan/mentransfer pengetahuan dan keterampilan yang sudah ada untuk menjawab pertanyaan yang belum terjawab atau situasi yang sulit, 
sehingga kemampuan pemecahan masalah matematis merupakan salah satu kemampuan dasar matematika yang harus dimiliki oleh setiap siswa (Syazali, 2015; Wijayanti, 2013). Pada umumnya, pemecahan masalah dengan matematika dan sains dapat dikaitkan, namun sebenarnya pemecahan masalah itu dapat terjadi secara nyata pada semua domain konten (content domain). Pemecahan masalah merupakan pusat pembelajaran matematika (Widyastuti, 2015). Dengan belajar memecahkan masalah maka peserta didik diberi banyak kesempatan untuk menghubungkan ide matematika dan untuk mengembangkan pemahaman konseptual. Pada kenyataannya, kemampuan pemecahan masalah dalam matematika tetap menjadi permasalahan yang paling mendasar.

Tidak dapat dipungkiri jika kemampuan pemecahan masalah matematis siswa masih belum menggembirakan. Dalam penelitian terdahulu, kemampuan pemecahan masalah matematis peserta didik masih tergolong rendah (Gusnidar, Netriwati, \& Putra, 2018); (Putra F. G., 2017). Rendahnya kemampuan pemecahan masalah matematis peserta didik diduga dipengaruhi model pembelajaran yang digunakan oleh guru. Pemilihan model pembelajaran yang tepat akan membantu peserta didik dalam memahami materi dengan lebih baik. Agar peserta didik mampu memecahkan masalah yang dihadapi dalam kegiatan belajar, maka peserta didik harus lebih tekun dan giat dalam belajarnya. Oleh karena hal itu, kemampuan pemecahan masalah matematis sangat diperlukan bagi setiap peserta didik dalam pembelajaran matematika karena kemampuan pemecahan masalah matematis yang diperoleh dalam pembelajaran matematika dapat digunakan dan diterapkan dalam memecahkan atau menyelesaikan masalah di kehidupan sehari-hari (Yuliasari, 2017). Oleh karena itu, untuk mempermudah peserta didik dalam menguasai kemampuan pemecahan masalah dalam proses belajar dibutuhkan model pembelajaran yang tepat dan sesuai dengan materi pembelajaran. Salah satu model pembelajaran kooperatif yang dapat digunakan adalah model pembelajaran osborn.

Model pembelajaran osborn merupakan cara merekonstruksi suatu pemikiran agar dapat digunakan untuk mengemukakan ide atau gagasan dengan tepat (Nurafifah, Nurlaelah, \& Usdiyana, 2016). Penerapan model pembelajaran osborn dapat mengembangkan gagasan dalam pemecahan masalah, selain itu peserta didik menjadi lebih kreatif. (Nugroho, 2016). Dalam penelitian ini, peneliti juga ingin menggunakan salah satu teknik pembelajaran di dalam model pembelajaran osborn untuk membedakan penelitian ini 
dengan penelitian sebelumnya. Salah satu teknik yang digunakan dalam proses pembelajaran adalah dengan menggunakan teknik mnemonic. Pemilihan teknik mnemonic ini dirasa cocok untuk diterapkan di dalam model pembelajaran osborn.

Tehnik mnemonic sering disebut dengan jembatan keledai yang merupakan metode untuk meningkatkan daya ingat dan hasilnya terlihat pada prestasi belajar mengalami kenaikan pada nilai peserta didik berdasar standar kumulatif yaitu mencapai diatas 75\% (Arya, Rochaminah, \& Hadjar, 2016). Menurut (Halwia, 2016) dalam proses mengingat terdapat tiga tahap yaitu tahap penyandian, penyimpanan, dan pemanggilan kembali. Pada penelitian ini penggunaan model pembelajaran osborn dengan teknik mnemonic memberikan peserta didik pengalaman dan kemampuan belajar yang berkaitan dengan permasalahan-permasalahan aktual yang terjadi dilingkungannya. Teori pembelajaran yang sangat mendukung dalam penelitian model pembelajaran osborn dengan teknik mnemonic ini salah satunya adalah teori konstruktivisme.

Menurut Jean Piaget dalam (Lamijan, 2016) menyatakan bahwa teori konstruktivisme adalah pengetahuan yang diperoleh seorang anak yang merupakan hasil dari konstruksi pengetahuan awal yang telah dimiliki dengan pengetahuan yang baru diperolehnya. Hal ini sejalan dengan yang diungkapkan oleh (Paradesa, 2015) menyatakan bahwa konstruktivisme adalah suatu pendekatan yang berkeyakinan bahwa orang secara aktif membangun atau membuat pengetahuan sendiri dan realitas ditentukan oleh pengalaman orang itu sendiri.

Dalam hal ini, peneliti akan mencari pengaruh antara model pembelajaran osborn dengan teknik mnemonic melalui teori konstruktivisme terhadap kemampuan pemecahan masalah matematis peserta didik dengan tujuan untuk mengetahui apakah terdapat pengaruh model pembelajaran osborn dengan teknik mnemonic melalui teori konstruktivisme terhadap kemampuan pemecahan masalah matematika peserta didik.

Sebelumnya, sudah pernah dilakukan penelitian terkait masalah ini, diantaranya oleh Putra, namun menggunakan pendekatan kontekstual berbantuan HoA, sedangkan penulis melakukan penelitian dengan menggunakan teori konstruktivisme. Penelitian pemecahan masalah matematis lain juga dilakukan oleh Syazali, menggunakan model probrem base learning berbantuan Maple II, Namun penelitian ini menggunakan model osborn dengan tehnik mnemonic. 


\section{METODE PENELITIAN}

Penelitian ini menggunakan metode penelitian eksperimen karena penulis akan mencari perbedaan treatment (perlakuan) tertentu. Jenis metode eksperimen yang digunakan adalah quasy experimental design. Populasi pada penelitian ini ialah siswa kelas VII SMP Muhammadiyah 1 Purbolinggo tahun ajaran 2017/2018. Teknik pengambilan sampel yang digunakan adalah random sampling. Sampel dalam penelitian ini adalah kelas VII.1, yaitu kelas yang diterapkan model pembelajaran model pembelajaran osborn, kelas VII.2, yaitu kelas yang diterapkan model pembelajaran model pembelajaran osborn dengan teknik mnemonic melalui teori konstruktivisme dan kelas VII.3, yaitu kelas yang diterapkan model pembelajaran konvensional. Instrumen yang digunakan dalam penelitian ini adalah instrumen tes (tes kemampuan pemecahan masalah matematis peserta didik). Teknik analisis data dalam pengujian hipotesis menggunakan uji ANAVA satu jalur sel tak sama.

\section{HASIL PENELITIAN DAN PEMBAHASAN}

Berdasarkan hasil uji validitas, tingkat kesukaran dan daya beda diperoleh 5 butir soal yang sesuai dengan kriteria dan siap digunakan untuk diujikan ke peserta didik. Setelah soal yang telah memenuhi kriteria diujikan kepada peserta didik, maka selanjutnya dilakukan uji normalitas dan uji homogenitas.

a. Uji Normalitas

Uji normalitas data dengan menggunakan metode Lilifors terhadap hasil tes kemampuan pemecahan masalah matematis peserta didik dilakukan pada masing-masing kelompok eksperimen 1 (kelompok kolom $\mathrm{A}_{1}$ ), kelompok eksperimen 2 (kelompok kolom $A_{2}$ ), kelompok kontrol (kelompok kolom $A_{3}$ ). Hasil uji normalitas yang telah dilakukan adalah sebagai berikut:

Tabel 1. Rangkuman Hasil Uji Normalitas Data Kemampuan Pemecahan Masalah Matematis

\begin{tabular}{clccc}
\hline No & \multicolumn{1}{c}{ Kelas } & $\boldsymbol{L}_{\text {maks }}$ & $\boldsymbol{L}_{\mathbf{0 , 0 5} ; \boldsymbol{n}}$ & Keputusan Uji \\
\hline 1 & Eksperimen 1 $\left(\mathrm{A}_{1}\right)$ & 0,182 & 0,190 & $\mathrm{H}_{0}$ diterima \\
2 & Eksperimen 2 $\left(\mathrm{A}_{2}\right)$ & 0,172 & 0,190 & $\mathrm{H}_{0}$ diterima \\
3 & Kontrol $\left(\mathrm{A}_{3}\right)$ & 0,167 & 0,190 & $\mathrm{H}_{0}$ diterima \\
\hline \multicolumn{4}{l}{ Sumber: Pengolahan Data }
\end{tabular}


Pada tabel 1, nilai $\mathrm{L}_{\text {maks }}$ untuk setiap kelompok kurang dari $\mathrm{L}_{0,05 ; n}$ yang berarti bahwa bahwa setiap kelompok penelitian berasal dari populasi yang berdistribusi normal.

\section{b. Uji Homogenitas}

Uji homogenitas dilakukan pada data kemampuan pemecahan masalah matematis peserta didik. Uji varians data penelitian ini menggunakan uji Bartlett. Hasil pengujian uji homogenitas dengan taraf signifikansi $(\alpha)=5 \%$ telah tercantum pada rangkuman tabel berikut ini:

Tabel 2. Hasil Uji Homogenitas

\begin{tabular}{ccccc}
\hline No & Kelompok & $\boldsymbol{x}^{\mathbf{2}}$ tabel & $\boldsymbol{x}^{\mathbf{2}}{ }_{\text {hitung }}$ & Keputusan Uji \\
\hline 1 & $\mathrm{~A}_{1}, \mathrm{~A}_{2}$ dan $\mathrm{A}_{3}$ & 5,991 & 1,113 & $\mathrm{H}_{0}$ diterima \\
\hline
\end{tabular}

Hasil uji homogenitas, nilai $\chi^{2}{ }_{\text {hitung }}$ untuk setiap kelompok kurang dari $\chi_{\text {tabel }}^{2}$ ini berarti bahwa data pada setiap kelompok berasal dari populasi yang homogen yang artinya setiap kelompok mempunyai variansi (kemampuan) yang sama.

Setelah dilakukan uji normalitas dan uji homogenitas, maka dilanjutkan uji hipotesis penelitian yaitu Uji Analisis Variansi Satu Jalur. Maka selanjutnya diadakan uji coba hipotesis penelitian diantaranya analisis variansi satu jalur sel tak sama. Rangkuman uji analisis variansi dua jalur sel tak sama disajikan pada tabel 3 .

Tabel 3. Rangkuman Analisis Variansi Satu Jalan Sel Tak Sama

\begin{tabular}{cccccc}
\hline Sumber & JK & dK & RK & $\boldsymbol{F}_{\text {obs }}$ & $\mathrm{F}_{\mathrm{a}}$ \\
\hline Model Pembelajaran & 892,933 & 2 & 446,467 & 4,376 & 3,159 \\
Galat & 5815,000 & 57 & 102,018 & - & - \\
\hline Total & 6707,933 & 59 & - & - & - \\
\hline
\end{tabular}

Berdasarkan tabel 3, rangkuman analisis variansi satu jalan sel tak sama didapatkan bahwa $\mathrm{F}_{\mathrm{a}}=4,376$ dan taraf signifikansi $5 \%$ diperoleh $F_{(0,05 ; 2 ; 87)}=$ 3,159 sehingga $\mathrm{F}_{\mathrm{a}}>F_{(0,05 ; 2 ; 87)}$ yang menunjukkan bahwa $H_{0}$ ditolak berarti terdapat pengaruh model pembelajaran osborn dengan teknik mnemonic melalui teori konstruktivisme terhadap kemampuan pemecahan masalah matematis peserta didik. Berikut disajikan tabel rerata marginal untuk kebutuhan uji Sceffe'. 
Tabel 4. Hasil Rerata Marginal

\begin{tabular}{lc}
\hline Model Pembelajaran & Rataan Marginal \\
\hline $\begin{array}{l}\text { Model pembelajaran osborn dengan teknik mnemonic } \\
\text { melalui teori konstruktivisme }\left(\mathrm{A}_{1}\right)\end{array}$ & 78,174 \\
Model pembelajaran osborn $\left(\mathrm{A}_{2}\right)$ & 76,838 \\
Konvensional/ metode ceramah $\left(\mathrm{A}_{3}\right)$ & 72,599 \\
\hline
\end{tabular}

Berdasarkan tabel 3, telah diketahui bahwa perhitungan analisis variansi satu jalur dengan sel tak sama bahwa $H_{0}$ ditolak, dengan ini berarti ada perbedaan antara model pembelajaran osborn dengan teknik mnemonic dalam menyelesaikan kemampuan pemecahan masalah matematis lebih baik dari pada model konvensional, sehingga perlu dilakukan uji komparasi ganda antar baris, yakni model pembelajaran osbron dengan teknik mnemonic $\left(\mu_{1}\right)$, model pembelajaran osbron $\left(\mu_{2}\right)$, model pembelajaran konvensional $\left(\mu_{3}\right)$. Rangkuman uji komparasi ganda antara baris disajikan dalam tabel 5.

Tabel 5. Uji Komparasi Ganda

\begin{tabular}{ccccc}
\hline No & Interaksi & $\mathbf{F}_{\text {hitung }}$ & $\mathbf{F}_{\text {tabel }}$ & Kesimpulan \\
\hline 1 & $\mu_{1}$ vs $\mu_{2}$ & 5,052 & 6,318 & $\mathrm{H}_{0}$ Diterima \\
2 & $\mu_{1}$ vs $\mu_{3}$ & 7,764 & 6,318 & $\mathrm{H}_{0}$ Ditolak \\
3 & $\mu_{2}$ vs $\mu_{3}$ & 0,283 & 6,318 & $\mathrm{H}_{0}$ Diterima \\
\hline
\end{tabular}

Berdasarkan tabel 5, pada hipotesis $\mathrm{H}_{0}$ pertama $\left(\mu_{1}\right.$ vs $\left.\mu_{2}\right)$ diperoleh kesimpulan bahwasanya $\mathrm{H}_{0}$ diterima. Hal ini berarti bahwa kemampuan pemecahan masalah peserta didik dengan perlakuan model pembelajaran osborn dengan teknik mnemonic melalui teori konstruktivisme tidak memiliki perbedaan dengan kemampuan pemecahan masalah peserta didik dengan perlakuan model pembelajaran osborn. Pada hipotesis $\mathrm{H}_{0}$ kedua $\left(\mu_{1}\right.$ vs $\left.\mu_{3}\right)$ diperoleh kesimpulan bahwasanya $\mathrm{H}_{0}$ ditolak. Hal ini berarti bahwa terdapat perbedaan kemampuan pemecahan masalah peserta didik yang mendapat perlakuan model pembelajaran osborn dengan teknik mnemonic melalui teori konstruktivisme dan model pembelajaran konvensional. Berdasarkan tabel 4, dapat dilihat bahwa rerata model pembelajaran osborn dengan teknik mnemonic melalui teori konstruktivisme lebih tinggi dibandingkan model pembelajaran konvensional yang berarti bahwa model pembelajaran osborn dengan teknik mnemonic melalui teori konstruktivisme lebih baik dibandingkan model pembelajaran konvensional terhadap kemampuan pemecahan masalah peserta didik. Pada hipotesis $\mathrm{H}_{0}$ ketiga $\left(\begin{array}{lll}\mu_{2} & \text { vs } & \mu_{3}\end{array}\right)$ 
diperoleh $\mathrm{H}_{0}$ diterima. Hal ini berarti bahwa kemampuan pemecahan masalah peserta didik dengan perlakuan model pembelajaran osborn tidak memiliki perbedaan dengan kemampuan pemecahan masalah peserta didik dengan perlakuan model pembelajaran konvensional. Hasil penelitian ini sama dengan beberapa hasil penelitian sebelumnya yang mengungkapkan bahwa pembelajaran dengan model osborn melalui teori konstrutivisme dalam menyelesaikan kemampuan pemecahanan masalah matematis siswa lebih baik dari pada metode konvensional, karena teori konstruktivisme sejatinya mengedepankan proses belajar bukan hasil (Sundawan, 2014; Nurafifah, Nurlaelah, \& Usdiyana, 2016). Selain itu (Justisuda, 2017) dalam penelitiannya mengungkapkan bahwa terdapat pengaruh positif penggunaan pendekatan konstruktivisme pada pembelajaran terhadap kemampuan pemecahan masalah matematik peserta didik.

\section{SIMPULAN}

Berdasarkan teori dan hasil analisis serta pengolahan data, maka dapat disimpulkan bahwa terdapat pengaruh kemampuan pemecahan masalah matematis peserta didik dengan penerapan model pembelajaran osborn dengan teknik mnemonic melalui teori kontruktivisme. Hal ini membuktikan bahwa kemampuan pemecahan masalah matematika peserta didik lebih efektif dengan model pembelajaran osborn dengan teknik mnemonic melalui teori konstruktivisme daripada model pembelajaran konvensional.

\section{DAFTAR PUSTAKA}

Ahdar, Rochaminah, S., \& Hadjar, I. (2016). Penerapan model pembelajaran langsung denganbantuan teknik mnemonik untuk meningkatkan hasil belajar matematika siswa pada materi perbandingan teknik komputer jaringan (TKJ) di SMKN 1 Parigi di kelas X. AKSIOMA: Jurnal Pendidikan Matematika, 5 (3), 137-151.

Aida, E., \& Widjajanti, D. B. (2014). Pengembangan perangkat pembelajaran teorema pythagoras dengan media berbantuan komputer. Jurnal Riset Pendidikan Matematika (JRPM), 1 (2), 216-226.

Greer, B., Verschaffel, L., \& Mukhopadhyay, S. (2007). Modelling for life: Mathematics and children's experience. 8. Modelling and applications in mathematics education. 
Gusnidar, G., Netriwati, N., \& Putra, F. G. (2018). Implementasi strategi pembelajaran konflik kognitif berbantuan software wingeom dalam meningkatkan kemampuan pemecahan masalah matematis. Jurnal Edukasi Matematika dan Sains, 5 (2), 62-69.

Halwia, H. (2016). Peningkatan hasil belajar melalui teknik mnemonic pada pembelajaran matematika di kelas VIIA MTs Muhammadiyah Syuhada kota Makassar. Skripsi. Makassar: Repository UIN Alauddin Makassar.

Kilpatrick, J., Swafford, J., \& \& Findell, B. (2001). Adding it up. Helping children lern mathematics. Washington, D. C.: National Academy Press.

Mawaddah, S., \& Anisah, H. (2015). Kemampuan pemecahan masalah matematis siswa pada pembelajaran matematika dengan menggunakan model pembelajaran generatif (generative learning) di SMP. EDU-MAT Jurnal Pendidikan Matematika, 3 (2), 166-175.

Nugroho, A. S. (2016). Pengaruh model pembelajaran osborn terhadap keterampilan berpikir kreatif pada peserta didik sekolah dasar. INOVASI, 18 (2), 1-6.

Nurafifah, L., Nurlaelah, E., \& Usdiyana, D. (2016). Model pembelajaran obstorn untuk meningkatkan kemampuan pemecahan masalah matematis siswa. M A T H L I N E Jurnal Matematika dan Pendidikan Matematika, 1 (2), 93-102.

Ormrod, J. E. (2008). Psikologi pendidikan (membantu siswa tumbuh dan berkembang. Jakarta: Erlangga.

Paradesa, R. (2015). Kemampuan berpikir kritis matematis mahasiswa melalui pendekatan konstruktivisme pada matakuliah matematika keuangan. Jurnal Pendidikan Matematika RAFA, 1 (2), 306-325.

Putra, F. G. (2017). Eksperimentasi pendekatan kontekstual berbantuan Hands on Activity (HoA) terhadap kemampuan pemecahan masalah matematik. Al-Jabar: Jurnal Pendidikan Matematika, 8 (1), 73-80.

Rizki, N. W. (2016). Pengembangan media cai mata pelajaran bahasa Mandarin materi pengenalan waktu kelas X SMKN 2 Jombang. Jurnal Mahasiswa Teknologi Pendidikan, 7 (3), 41-49.

Syazali, M. (2015). Pengaruh model pembelajaran creative problem solving berbantuan maple II terhadap kemampuan pemecahan masalah matematis. Al-Jabar: Jurnal Pendidikan Matematika, 6, 91-98. 
Widyastuti, R. (2015). Proses berpikir siswa dalam menyelesaikan masalah matematika berdasarkan teori Polya ditinjau dari adversity quotient tipe climber. Al-Jabar : Jurnal Pendidikan Matematika, 6, 183-193.

Widyawati, S. (2017). Pengaruh kemampuan koneksii matematis siswa teerhadap prestasi belajar matematika ditinjau dari gaya belajar pada materi bangun datar siswa kelas IX SMP di kota Metro. Iqra': Jurnal Kajian Ilmu Pendidikan, 1, 47-67.

Wijayanti, P. S. (2013). Pengaruh Pendekatan MEAs terhadap kemampuan pemecahan masalah, komunikasi matematis, dan kepercayaan diri siswa. PYTHAGORAS: Jurnal Pendidikan Matematika, 8 (2), 181-192.

Wulandari, P., Mujib, \& Putra, F. G. (2016). Pengaruh model pembelajaran investigasi kelompok berbantuan perangkat lunak maple terhadap kemampuan pemecahan masalah matematis. Al-Jabar: Jurnal Pendidikan Matematika, 7 (1), 101-106.

Yuliasari, E. (2017). Eksperimentasi model PBL dan model GDL terhadap kemampuan pemecahan masalah matematis ditinjau dari kemandirian belajar. JIPM (Jurnal Ilmiah Pendidikan Matematika), 6 (1), 1-10.

Yusnita, I., Masykur, R., \& Suherman. (2016). Modifikasi model pembelajaran Gerlach dan Ely melalui integrasi nilai-nilai keislaman sebagai upaya meningkatkan kemampuan representasi matematis. Al-Jabar: Jurnal Pendidikan Matematika, 7 (1), 29-38. 